\title{
Gorzkie żale jako forma oratoryjna na przyktadzie kompozycji Kazimierza Garbusińskiego
}

\section{Nota biograficzna Kazimierza Grarbusińskiego}

W 2015 roku przypada 70. rocznica śmierci Kazimierza Garbusińskiego (1883-1945), ważnej postaci muzycznego życia Krakowa w okresie międzywojennym. Kazimierz Garbusiński urodził się 25 lutego 1883 roku w Opatowcu w ziemi kieleckiej ${ }^{1}$. Pierwsze wiadomości o muzyce zdobywał u swego brata Piotra. Następnie udał się do Warszawy, gdzie był uczniem Zygmunta Noskowskiego (1903-1904). W latach 1904-1908 studiował muzykę kościelną w Konserwatorium Towarzystwa Muzycznego u Władysława Żeleńskiego (1904-1908). Żeleński uczył go gry na organach, fortepianie, a następnie także kompozycji. Kontrapunktu uczył się u Feliksa Nowowiejskiego, który wówczas przebywał w Krakowie. Po ukończeniu studiów (1908), mimo atrakcyjnych ofert zatrudnienia w Ameryce czy na Śląsku, postanowił poświęcić się pracy w Krakowie. Od 1909 roku był związany z kościołem pw. św. Anny w Krakowie, gdzie pełnił obowiązki organisty. Przy tym kościele na bazie zorganizowanego przez siebie w 1915 roku zespołu wokalno-instrumentalnego powołał do istnienia Towarzystwo Oratoryjne, którym kierował w latach 1919-1924. Działalność koncertowa Garbusińskiego jako dyrygenta Towarzystwa Oratoryjnego umożliwiła krakowianom kontakt z takimi dziełami, jak: Stworzenie świata Josepha Haydna, Boże Narodzenie Camille’a Saint-Saënsa, Siedem stów Chrystusa François Clément Théodore’a

\footnotetext{
1 Wiadomości biograficzne na podstawie: Kazimierz Garbusiński (W 30-lecie dziatalności artystycznej), „Dzwon Niedzielny”, R. 15 (1939) nr 1, s. 6-7; por. Twórczość Kazimierza Garbusińskiego (W 30-lecie dziatalności artystycznej), „Dzwon Niedzielny” R. 15 (1939) nr 4, s. 4-5; por. M. Perkowska, Garbusiński Kazimierz, [w:] Encyklopedia muzyczna PWM, t. 3 EFG, red. E. Dziębowska, Kraków 1987, s. 231; por. J. Krassowski, Garbusiński Kazimierz, [w:] Kompozytorzy polscy 1918-2000, t. 2, Biogramy, red. M. Podhajski, GdańskWarszawa 2005, s. 234-235.
} 
Dubois, Stabat Mater Giovanniego Battisty Pergolesiego, Wskrzeszenie Łazarza Lorenzo Perosiego. Garbusiński miał więc podobne zasługi, co inny wielki muzyk okresu międzywojennego - Bolesław Wallek-Walewski².

Już w roku 1909 Garbusiński rozpoczął działalność pedagogiczną jako nauczyciel śpiewu i muzyki w krakowskich gimnazjach. W Konserwatorium Towarzystwa Muzycznego w Krakowie wykładał w latach 1928-1939. Prowadził tu klasę organów, chór oraz przedmioty teoretyczne 3 . Dbał o dobry poziom muzyki kościelnej wykładanej na tej uczelni. W samym tylko roku 1939 na organistów kształciło się 40 kandydatów, co obrazuje zainteresowanie i wagę studiów organmistrzowskich. Wielu spośród uczniów Garbusińskiego znalazło zatrudnienie w innych diecezjach. Był także prezesem Związku Organistów w Krakowie, założycielem krótko funkcjonującego męskiego Chóru Kościelnego im. Grzegorza Gerwazego Gorczyckiego, współpracował z Echem Krakowskim w charakterze korepetytora chóralnego, organizował audycje muzyczne dla młodzieży szkolnej w teatrze przy ul. Rajskiej. Był honorowym członkiem założonego w 1929 roku Związku Chórów Kościelnych archidiecezji krakowskiej. Owocem pracy pedagogicznej w szkołach są jego podręczniki (Dyktaty muzyczne, dwa tomy Melodii) oraz wiele opracowań i pieśni na użytek szkół.

Kazimierz Garbusiński był cenionym kompozytorem, dzisiaj jest zupełnie zapomniany. Sam fakt, iż uczyli go kompozytorzy tej miary co Zygmunt Noskowski, Feliks Nowowiejski oraz Władysław Żeleński, sprawia, że był on twórcą, który opanował solidne rzemiosło kompozytorskie, posługując się językiem muzycznym w estetyce późnego romantyzmu. Garbusiński był przede wszystkim kompozytorem muzyki religijnej. Ta dziedzina twórczej działalności wypływała nie tylko z pól jego aktywności zawodowej, ale przede wszystkim z głębokiej i szczerze przeżywanej wiary. Pozostawił po sobie kilkanaście mszy, oratoriów, kantaty świeckie, kościelne, wiele pieśni chóralnych i opracowań. W przedwojennej, polskiej twórczości oratoryjnej jego dorobek wzbogaca efekty pracy innych twórców, takich jak: Józef Elsner, Mieczysław Sołtys, Eugeniusz Gruberski, Władysław Żeleński i Feliks Nowowiejski. Pierwszym oratorium Garbusińskiego było skomponowane w 1919 roku, a prawykonane w 1920 roku Siedem stów Chrystusa do słów Antoniego Waśkowskiego. Kolejne oratoria: Św. Franciszek z Asyżu (do tekstu Ludwika Kondratowicza); Boże Narodzenie (w formie suity pastoralnej w trzech częściach, osnutej na motywach polskich kolęd); Gorzkie żale (miste-

2 Por. W. Kałamarz, Bolestaw Wallek-Walewski i jego twórczość na chór mieszany, „Pro Musica Sacra” nr 12 (2014), s. 120-122.

3 Por. T. Przybylski, $Z$ dziejów nauczania muzyki w Krakowie. Od średniowiecza do czasów wspótczesnych, Kraków 1994, s. 72, 193, 202, 206. 
rium pasyjne w czterech częściach). Zbliżone do form oratoryjnych są: Crux fidelis (w dwóch częściach, 1929); Lauda Sion (hymn eucharystyczny, 1931); Laudate Dominum (Psalm 116, 1931); Te Deum laudamus (hymn, 1931); Dies irae, czyli Sąd ostateczny (fantazja na orkiestrę symfoniczną, deklamację, mezzosopran solo i chóry, 1933). Do formy oratorium nawiązują także świeckie dzieła: Chór Dyabtów (poemat na chór męski z towarzyszeniem orkiestry do tekstu Krasińskiego, 1925); Sto lat my już bezcieleśni (kantata na sola, chór mieszany i orkiestrę).

W jego twórczości mszalnej znajdujemy: Missa pastoralis - na chór męski z organami; Missa Quadragesimalis na chór męski a cappella; Missa in. hon. St. Josephi - na chór męski z organami; Missa sine titulo - na trzygłosowy chór męski a cappella; Missa in honorem St. Annae - na sześciogłosowy chór męski; Missa Gloria Tibi Trinitas na chór mieszany z towarzyszeniem organów ad libitum; Missa Bogurodzica - na chór mieszany i organy; Missa in. honorem St. Joannis Cantii - na chór męski z organami; Missa solemnis - na chór męski i orkiestrę lub organy; Missa Laudate Dominum na chór mieszany i orkiestrę lub organy (nagrodzona na konkursie Towarzystwa Wydawniczego Muzyki Polskiej w Warszawie w 1932); Missa pro defunctis; dwie msze do tekstów polskich.

Pośród wielu dzieł chóralnych a cappella z towarzyszeniem orkiestry lub organów na szczególną uwagę zasługują: Pięć psalmów nieszpornych i Magnificat - na chór męski i organy; Jutrznia wielkanocna - na chór męski i organy; hymn ku czci św. Jana Kantego Gentus Polonae gloria napisany dla akademickiego kościoła pw. św. Anny w Krakowie. Garbusiński ma też w dorobku zbiory pieśni: 60 pieśni kościelnych całego roku na trzygłosowy chór chłopięcy; 23 kolędy na chór mieszany; ponad 20 pieśni kościelnych całego roku na chór mieszany szkolny; ponad 20 pieśni świeckich na szkolny chór mieszany; ponad 20 pieśni ludowych na szkolny chór męski; 100 kolęd na chór męski; 104 pieśni kościelnych całego roku na chór męski. Stosunkowo niewiele natomiast pozostawił po sobie dzieł czysto instrumentalnych. Są to głównie preludia na organy i kwartety smyczkowe.

\section{Różne pomysły opracowania Gorzkich żali jako oratorium}

Jednym z oratoriów Kazimierza Garbusińskiego, bodaj najważniejszym, są Gorzkie żale. Na temat tego nabożeństwa istnieje dość obszerna literatura ${ }^{4}$. Garbusiński nie jest zresztą jedynym, który pomyślał, by w oparciu o nie napisać

${ }^{4}$ Oprócz podanej publikacji (zbioru referatów) Perty muzyki kościelnej: chorat gregoriański $i$ „Gorzkie żale”, red. R. Tyrała, W. Kałamarz, Kraków 2007, w której znajduje się mój artykuł (W. Kałamarz, W poszukiwaniu pierwotnej melodii), warto wspomnieć także o książce Michała Buczkowskiego Gorzkie żale. Między rozumem a uczuciem (Kraków 2010) oraz in- 
oratorium. W tamtym czasie z zamiarem skomponowania oratorium do tekstu Gorzkich żali nosił się Karol Szymanowski'. Informuje o tym m.in. ks. Hieronim Feicht w swym artykule ${ }^{6}$, dodając, że Gorzkie żale były ulubionym nabożeństwem Szymanowskiego. Niestety, Szymanowski zarówno tego, jak i innego zamiaru kompozycji religijnej, a mianowicie skomponowania mszy - nie zrealizował. Pozostawił za to inne piękne dzieła muzyki religijnej: Stabat Mater do przekładu Józefa Jankowskiego, Veni Creator do tekstu Stanisława Wyspiańskiego i Litanie do Marii Panny do dwóch fragmentów wiersza Jerzego Lieberta.

Inny polski kompozytor Andrzej Nikodemowicz na wybranych tekstach Gorzkich żali oparł swój utwór Ptacz u grobu Chrystusa Pana, prawykonany 19 marca 1981 roku w bazylice oo. Franciszkanów w Krakowie.

W 2007 roku w trzechsetlecie powstania nabożeństwa Gorzkich żali miały miejsce dwa artystyczne wydarzenia. 2 kwietnia przed Pałacem Kultury i Nauki w Warszawie w rocznicę śmierci Jana Pawła II miało miejsce Widowisko pasyjne w reżyserii Jerzego Bielunasa. Transmitowany przez Program 1 Telewizji Polskiej koncert stanowił współczesną wersję pasyjnego misterium sprzed wieków. Źródłem inspiracji dla twórców widowiska oprócz nabożeństwa Gorzkich żali były także pieśni wielkopostne i dzieła muzyki poważnej poświęcone tematyce męki Pańskiej. Utworom muzycznym towarzyszyły sceny pantomimiczne i tzw. żywe obrazy. Autorami scenariusza koncertu byli: Jan Pospieszalski, Halina Bisztyga i Jerzy Bielunas. Aranżacje muzyczne koncertu przygotował Marcin Pospieszalski ${ }^{7}$ W Lublinie zaś chór i orkiestra kameralna Jubilaeum pod dyrekcją Tomasza Orkiszewskiego 8 lutego 2007 roku nagrali płytę z trzema częściami nabożeństwa w muzycznym opracowaniu/aranżacji Tomasza Orkiszewskiego na sopran solo, chór i orkiestrę kameralną.

W 2011 roku powstało pasyjne oratorium autorstwa ks. Przemysława Pasternaka CM pt. Ta Hagia Pasche - Cierpienie Chrystusa, oparte na tekście i melodiach nabożeństwa Gorzkie żale, w obsadzie na solistów, chór i orkiestrę symfoniczną. Prawykonane w bazylice św. Wincentego à Paulo w Bydgoszczy pod dyrekcją kompozytora.

nym zbiorze referatów pokonferencyjnych poświęconych Gorzkim żalom: Gorzkie żale przybywajcie, red. S. Urbański, J. Śmigiera, Warszawa 2008.

5 Wspomnieć też trzeba o opracowaniu Gorzkich żali na organy Stanisława Moniuszki. Por. K. Duszyk, E. Dziębowska, Moniuszko Stanistaw, [w:] Encyklopedia muzyczna PWM, red. E. Dziębowska, t. 6 M, Kraków 2000, s. 327.

6 Por. H. Feicht, Karol Szymanowski. Wspomnienia i impresje, „Muzyka Polska” 14 (1937) z. 4, s. 203; por. W. Kałamarz, Karol Szymanowski w rękopisach Feichta, „Polski Rocznik Muzykologiczny" (2007-2008) nr 6, s. 44-45.

7 Por. www.wirtualnemedia.pl/artykul/tvp1-w-rocznice-smierci-jana-pawla-ii (31.12.2014). 


\section{Opis misterium pasyjnego Gorzkie żale Kazimierza Crarbusińskiego}

Jak się więc wydaje, Kazimierz Garbusiński jest pierwszym, który to polskie nabożeństwo ubrał w szatę wielkoobsadowego oratorium. Rękopis znajduje się w bibliotece Uniwersytetu Jagiellońskiego, podobnie jak i cała jego spuścizna kompozytorska. Niestety dostępne są tylko głosy i wyciąg. Brakuje partytury, stąd trudności w pełnej ocenie roli orkiestry. $\mathrm{Na}$ końcu brudnopisu podane jest miejsce i data „Kraków w sierpniu 1931”. Utwór został dedykowany Jego Ekscelencji Księciu Metropolicie Adamowi Stefanowi Sapiesze. Materiał tekstowy stanowi pobudka i pierwsza część nabożeństwa Gorzkich żali. Tekst jest zgodny z wersją zamieszczoną w Śpiewniku kościelnym ks. Jana Siedleckiego wydanym w 1928 roku, z niewielkimi modyfikacjami, np. w Lamencie duszy jest „Jezu mój” zamiast „Jezu”, w Smutnej rozmowie duszy jest „Miecz boleści Me serce przenika”, zamiast „Miecz Me serce przenika”. Nie biorę pod uwagę licznych powtórzeń fragmentów tekstu, co jest naturalną praktyką w tekście opracowywanym wokalnie, wielogłosowo. Obsadę stanowi trzech solistów: mezzosopran, tenor, bas oraz chór mieszany i orkiestra symfoniczna w składzie: 2 flety, 2 klarnety, 2 oboje, 2 fagoty, 2 trąbki in B, 4 waltornie, 3 puzony, tuba, organy i kwintet smyczkowy.

\subsection{Część pierwsza (Wstęp i Pobudka)}

Oratorium rozpoczyna liczący 91 taktów instrumentalny Wstęp w tempie andante misterioso, grany alla breve, o spokojnym, miarowym ruchu półnutowym. Wstęp otwiera partia oboju solo, wykonującego fragment tematu pobudki w krakowskiej wersji melodycznej, zapisanej w Śpiewniku kościelnym katolickim ks. Tomasza Flaszy. Dalszy materiał tematyczny oparty jest na fragmentach melodycznych Pobudki zwłaszcza tych descendentalnych. Można także wychwycić różne opisania dźwięków charakterystyczne dla odmiennych wersji, śpiewanych w krakowskich kościołach. Dynamika piano stopniowo urastająca do fortissimo, sukcesywne wprowadzanie kolejnych instrumentów smyczkowych, dętych blaszanych, grających współbrzmienia spokojne, acz bolesne, gdyż głównie w opadającym pochodzie chromatycznym, w spokojnym, miarowym rytmie. Kilka razy została użyta nuta pedałowa, podkreślająca centra tonalne g-moll i c-moll, pomiędzy którymi oscyluje ta część.

Pobudka wykonywana jest w zmiennej obsadzie wokalnej z towarzyszeniem orkiestry. Rozpoczyna ją czterogłosowy chór mieszany. Drugą i trzecią zwrotkę śpiewa mezzosopran solo z autonomiczną melodią, po czym z nowym, zewnętrznym wobec nabożeństwa Gorzkich żali tekstem wchodzi chór żeński określony 
w partyturze jako chór aniołów. Poszczególne żeńskie głosy imitacyjnie wprowadzają motywy Któryś za nas cierpiat rany. Mezzosopran kontynuuje czwartą zwrotkę Pobudki na tle lamentu aniołów (zewnętrzny tekst): „Ach! Ból, straszny ból, przenika cały świat". Po kilkunastu taktach utrzymanej w dramatycznym, mocno schromatyzowanym charakterze instrumentalnej wstawki z elementami tremola (niczym trzęsienie ziemi) tekst piątej zwrotki podejmuje bas solo. Jego deklamacyjna partia, wzbogacona fragmentem recytowanym, obejmuje trzy zwrotki. Z tekstem ósmej zwrotki Uderz, Jezu wchodzi chór mieszany unisono, kończąc tę zwrotkę opadającym pochodem całotonowym, po czym duet mezzosopranu i basu podejmuje wielokrotnie powtarzany tekst zwrotki dziewiątej. Ostatnią zwrotkę wykonuje chór mieszany najpierw unisono, następnie w pełnym brzmieniu, wracając do melodyki ludowego nabożeństwa (wersji krakowskiej), ograniczając się jedynie do jej wielogłosowego opracowania.

\subsection{Część druga (Hymn)}

Część drugą rozpoczyna krótki fragment instrumentalny zawierający melodię pierwszego wersu w wariancie krakowskim, zgodnym ze śpiewnikiem Tomasza Flaszy. Następnie temat podjęty jest naprzemiennie przez chóralne głosy męskie oraz głosy żeńskie (z drugim wersem tekstu), po dłuższym zaś fragmencie instrumentalnym cały chór na przemian z (chóralnym) sopranem solo jeszcze raz wykonuje te same słowa. Trzeci i czwarty wers pierwszej zwrotki kontynuuje (chóralny) sopran solo, śpiewając pochody chromatyczne, po czym cały chór unisono kończy pierwszą zwrotkę, przypominając słowa pierwszego wersu w melodii opartej na ekspresyjnym, napięciowym łuku. Zwrotkę drugą, po krótkim instrumentalnym łączniku, w całości śpiewa mezzosopran solo w rytmie spowolnionym, poddanym augmentacji i melice dość odmiennej od oryginału, opartej na pochodach chromatycznych. Po dramatycznym fragmencie instrumentalnym, znów opartym na przebiegach chromatycznych to w ruchu przeciwnym, to równoległym chór mieszany unisono i a cappella $\mathrm{w}$ dynamice forte na melodię krakowską śpiewa pierwszy wers trzeciej zwrotki. Odpowiada im krótko zespół instrumentalny, po czym chór a cappella kontynuuje w czterogłosie tekst, doprowadzając do kulminacji w trzecim wersie na słowach „za włosy targa”, zaś wycisza napięcie, cytując melodię na słowach: „znosi w cierpliwości, Król z wysokości”, następnie na tle instrumentalnego łącznika chór przypomina melodię Pobudki i tekst przewodni oratorium Gorzkie żale. Tekst czwartej zwrotki hymnu śpiewa tenor solo na tle chóru utrzymanego w dynamice piano i pianissimo, przeważnie unisono, przywołującego teksty „Gorzkie żale, przybywajcie” oraz „Żal duszę ściska, serce boleść czuje”. Melodia tenoru oparta na krokach sekundowych zmienia się w drama- 
tyczne, naprzemienne skoki kwintowe na tekście: „gdy zbrojną żołnierz rękawicą chlusta”. Ostatnia (piąta) zwrotka, śpiewana przez mezzosopran solo, ma charakter deklamacyjny na tle ostinatowych figur kwintowych w zespole instrumentalnym z solowymi dopowiedzeniami zmiennych instrumentów dętych.

\subsection{Część trzecia (Lament duszy nad cierpiącym Jezusem)}

Lament duszy w oryginalnej melodii ma charakter recytacji psalmodycznej. Kompozytor Kazimierz Garbusiński zachował ten charakter, nawiązując do oryginału w pierwszej zwrotce oraz w zwrotkach 7-9. W pozostałych twórca pozostawił jedynie charakter tej pieśni, melodycznie odchodząc od oryginału. Nie wiadomo, czemu kompozytor pominął szóstą zwrotkę, w jej miejsce wstawiając wielokrotne powtórzenie słów „Jezu mój kochany!”. Rozwinął także słowa intonacji początkowych wersów zwrotek, o czym była mowa na początku punktu. Obsada jest dość różnorodna: sola tenorowe, sola mezzosopranowe, sola basowe, tercet i chór. Dość ciekawy jest układ: zwrotki 1-2 na mezzosopran solo, zwrotki 3-4 na tenor solo wzbogacony mezzosopranowym zawołaniem kończącym zwrotkę Jezu mój kochany!; zwrotka 5 - na bas solo. Tutaj następuje tercet solistów wielokrotnie powtarzający słowa „Jezu mój kochany!”, po czym 7 zwrotkę śpiewa chór mieszany, 8 - mezzosopran solo, 9 - tenor solo, 10 - bas solo. I znów po tercecie solistów wielokrotnie powtarzającym słowa „Jezu mój kochany” następują wezwania końcowe „Bądź pozdrowiony”, śpiewane naprzemiennie przez chór mieszany i tercet solistów, wykonywane unisono lub w wielogłosie. Oczywiście całości towarzyszy zróżnicowana partia orkiestry.

\subsection{Część czwarta (Smutna rozmowa duszy)}

Także ostatnia część oratorium jest inteligentnie rozplanowana obsadowo. Zdarzeniowość zmienności obsady jest czynnikiem ubarwiającym krytykowaną przez pierwszych słuchaczy monotonię temp, nastroju, descendentalnych i schromatyzowanych linii melodycznych, nieustannie alterowanych akordów. Po instrumentalnym wstępie pierwszą zwrotkę śpiewa mezzosopran solo, kolejną bas solo, trzecią na tle oszczędnej partii skrzypiec solo (i orkiestry) deklamuje mezzosopran, czwartą duet tenoru i basu na tle dopowiedzeń chóru mieszanego. Po dłuższym fragmencie instrumentalnym z tekstem piątej zwrotki wchodzi znów deklamacja mezzosopranu na tle bardziej rozwiniętej partii skrzypiec solo i orkiestry. Szóstą zwrotkę, z wielokrotnie powtarzanym tekstem „niech czuję gwałt”, śpiewają kolejno chór mieszany, bas solo, chór żeński, chór mieszany ze zwielokrotnionymi głosami podziałami w głosach żeńskich i basach. Zwrócić nale- 
ży uwagę, iż kompozytor zachował tradycyjny układ rozmowy pomiędzy Matką (głos żeński) a duszą (głos/y męski/e).

\section{Recenzje wykonań przedwojennych}

Wiemy o dwóch wykonaniach tego oratorium, obydwu z marca 1932 roku: w Krakowie i Poznaniu. W lokalnej prasie pojawiły się zapowiedzi i recenzje z koncertów autorstwa muzyków tej miary co Zdzisław Jachimecki, Michał Julian Piotrowski i Stanisław Wiechowicz.

Z. J. (prawdopodobnie Zdzisław Jachimecki) w krakowskim dzienniku „Głos Narodu” zwrócił uwagę na nawiązujący do stylu szkoły ratyzbońskiej wstęp muzyczny (I część oratorium) i nowszy estetycznie materiał muzyczny pozostałych trzech części oratorium Garbusińskiego, w których to dalszych częściach kompozytor nie wahał się użyć dysonansów, zachowując jednak właściwy stylowi kościelnemu umiar w ich występowaniu ${ }^{8}$. Autor recenzji zwrócił też uwagę na przewagę rytmiki modalnej z upodobaniem rytmów trocheicznych i daktylicznych.

O szczegółach krakowskiego (pra)wykonania dowiadujemy się z recenzji Michała Juliana Piotrowskiego9. Oratorium wykonano w piątek 4 marca 1932 roku o godz. 20.00 w Sali Złotej Domu Katolickiego w Krakowie siłami połączonych chórów Towarzystwa Muzycznego, uczniów Konserwatorium Muzycznego, orkiestry symfonicznej pod dyrekcją Bolesława Wallek-Walewskiego. Jako soliści wystąpili Elza Sękarówna, Józef Stępniowski, Adam Mazanek.

Wykonanie poznańskie w „Kurierze Poznańskim” z 23 marca 1932 roku opisał Stanisław Wiechowicz ${ }^{10}$. Do wystawienia Gorzkich żali w stolicy Wielkopolski doszło siłami chóru i orkiestry poznańskiego Konserwatorium Państwowego pod dyrekcją Zygmunta Latoszewskiego. W kompozycji Garbusińskiego Wiechowicz docenił piękną i napięciową, zakorzenioną w duchu kościelnym melodykę oraz zespoloną z nią harmonikę i instrumentację. Jako mankament dzieła Wiechowicz wytkną brak momentów kontrastujących: „Wszystkie części są wolne i dosyć ciężkie - ożywienie ich wpłynęłoby dodatnio na tok całości. Jest to w każdym razie jedno z wartościowszych dzieł, jakie się ukazały u nas w dziedzinie chóralnej w ostatnich czasach"11. Podobne wrażenie miał inny autor recenzji (Alf. Jen.),

8 Por. Z. J[achimecki], Z Sali koncertowej, „Głos Narodu” 39 (1932) nr 68, s. 5.

9 Por. M. J[ulian] Piotrowski, Z Sali koncertowej. Gorzkie żale - K. Garbusińskiego, "Czas” 84 (1932) nr 56, s. 3.

${ }^{10}$ Por. S. Wiechowicz, Z estrady. Audycja Konserwatorium, „Kurier Poznański” 27 (1932) nr 135, s. 4.

${ }^{11}$ S. Wiechowicz, $Z$ estrady, dz. cyt., s. 4. 
który zwrócił uwagę na osłabiające napięcie całości interludia orkiestrowe, homofonię i monorytmikę ${ }^{12}$.

\section{Streszczenie}

Gorzkie żale jako forma oratoryjna na przykładzie kompozycji Kazimierza Garbusińskiego

Forma oratorium nie jest zbyt licznie reprezentowana w środowisku polskich twórców muzycznych. Warto więc przypomnieć o istnieniu dzieła dzisiaj niewykonywanego, mającego swą premierę przed wojną. Tym bardziej, jeśli jest to utwór bazujący na niezwykle popularnym polskim nabożeństwie ludowym, a jego twórcą jest ceniony przed wojną kompozytor i działacz muzyczny stolicy Małopolski. Gorzkie żale Kazimierza Garbusińskiego zdobyły dobre recenzje przed wojną, zdaniem znawców jego muzyki są najlepszym utworem tego kompozytora i zasługują nie tylko na omówienie, ale także ponowne wykonanie współcześnie.

\section{Summary}

\section{Lenten Lamentations as a Form of Oratorio on the Example of Composition by Kazimierz Garbusiński}

Oratorio as a musical form is not very well represented among Polish music artists. Therefore, it is worth to mention the existence of a composition which premiered before the war but is no longer performed today. All the more so that it is a work based on the extremely popular Polish folk worship act as well as that its author is a composer and music activist valued before the war and creating in the capital of Małopolska. Lenten lamentations by Kazimierz Garbusiński received good reviews before the war. According to the experts in his music they are the best music piece created by the composer and they deserve not only to be discussed but also to be performed in our times.

${ }^{12}$ Nie udało się ustalić pochodzenia wszystkich wycinków prasowych zgromadzonych przez kompozytora, dostępnych w Bibliotece Jagiellońskiej, wklejonych na końcu rękopisu wyciągu fortepianowego, s. 82-83. 
Stowa kluczowe Gorzkie żale, oratorium, Kazimierz Garbusinski, muzyka w Krakowie

Keywords Lenten lamentations, oratorio, Kazimierz Garbusiński, music in Kraków

\section{Bibliografia}

Buczkowski M., Gorzkie żale. Między rozumem a uczuciem, Kraków 2010.

Duszyk K., Dziębowska E., Moniuszko Stanistaw, [w:] Encyklopedia muzyczna PWM, t. 6 M, red. E. Dziębowska, Kraków 2000, s. 327.

Feicht H., Karol Szymanowski. Wspomnienia i impresje, „Muzyka Polska” 14 (1937) z. 4, s. 203. Gorzkie żale przybywajcie, red. S. Urbański, J. Śmigiera, Warszawa 2008.

J[achimecki] Z., Z Sali koncertowej, „Głos Narodu” 39 (1932) nr 68, s. 5.

Kałamarz W., Bolestaw Wallek-Walewski i jego twórczość na chór mieszany, „Pro Musica Sacra” nr 12 (2014), s. 120-122.

Kałamarz W., Karol Szymanowski w rękopisach Feichta, „Polski Rocznik Muzykologiczny” (2007-2008) nr 6, s. 44-45.

Kazimierz Garbusiński (W 30-lecie dziatalności artystycznej), „Dzwon Niedzielny” R. 15 (1939) nr 1, s. 6-7.

Krassowski J., Garbusiński Kazimierz, [w:] Kompozytorzy polscy 1918-2000, t. 2, Biogramy, red. M. Podhajski, Gdańsk-Warszawa 2005, s. 234-235.

Perkowska M., Garbusiński Kazimierz, [w:] Encyklopedia muzyczna PWM, t. 3 EFG, red. E. Dziębowska, Kraków 1987, s. 231.

Perty muzyki kościelnej: chorat gregoriański i „Gorzkie żale”, red. R. Tyrała, W. Kałamarz, Kraków 2007 (Pro Musica Sacra, 4).

Piotrowski M. J., Z Sali koncertowej. Gorzkie żale - K. Garbusińskiego, „Czas” 84 (1932) nr 56, s. 3.

Przybylski T., $Z$ dziejów nauczania muzyki w Krakowie. Od średniowiecza do czasów wspótczesnych, Kraków 1994.

Twórczość Kazimierza Garbusińskiego (W 30-lecie dziatalności artystycznej), „Dzwon Niedzielny" R. 15 (1939) nr 4, s. 4-5.

Rękopisy głosów do oratorium znajdujące się w Bibliotece Jagiellońskiej (brak sygnatury). Wiechowicz S., Z estrady. Audycja Konserwatorium, „Kurier Poznański” 27 (1932) nr 135, s. 4. 